\title{
GAYA HIDUP PUNKLUNG (Studi Kasus pada Komunitas Punklung di Cicalengka, Bandung)
}

\author{
Tri Esti Budiningsih dan Didit Setiawan \\ Jurusan Psikologi Fakultas Ilmu Pendidikan \\ Universitas Negeri Semarang
}

\begin{abstract}
This study aimed to know the lifestyle punklung in Cicalengka Bandung. Subjects of research were Punklung community. Methods of data collection using participant observation, interviews (the spokesman for the community and some members of the Punklung community). Research results presented in descriptive qualitative showed that punklung's lifestyle is influenced by several factors which are, attitudes, experiences and observations, motive, group's reference, and cultural transformation. Punklung lifestyle oriented to arts, namely music. Judging from the activity, they formed a band group, despite the stigma that exists in society considers negative assumption about punk kids, but there is also a punk kid whose life clean of negative things, punk Kids have a positive view of themselves and others. Key factors which driving young people to join the community of the greatest punk because of the encouragement of it in those who want to be punk or having a like to punk because of their great interest towards punk which is used as a medium for self-expression and as a search for their own identity. Factors outside their milieu that they were mostly children punk.
\end{abstract}

Key words: punk, lifestyle

\begin{abstract}
Abstrak
Penelitian ini bertujuan mengetahui gaya hidup punklung di Cicalengka Bandung. Subjek penelitian adalah komunitas Punklung. Metode pengumpulan data menggunakan observasi partisipan, wawancara (terhadap juru bicara komunitas Punklung dan beberapa anggota komunitas Punklung). Hasil penelitian yang dipaparkan secara deskriptif kualitatif menunjukan bahwa Gaya hidup punklung dipengaruhi oleh beberapa faktor yaitu sikap, pengalaman dan pengamatan, motif, kelompok referensi, dam transformasi budaya. Gaya hidup punklung berorientasi pada bidang seni, yaitu musik. Dilihat dari aktivitas, mereka membentuk group band, meskipun stigma yang ada di masyarakat menganggap negatif tentang anak punk, tetapi ada juga anak punk yang hidupnya bersih dari hal-hal negatif, Anak punk mempunyai pandangan yang positif terhadap dirinya sendiri dan orang lain. Faktor pendorong anak muda masuk dalam komunitas punk yang terbesar karena dorongan dari dalam diri mereka yang ingin menjadi anak punk atau suka dengan punk karena minat mereka yang besar terhadap punk yang dijadikan sebagai media untuk mengekspresikan diri dan sebagai pencarian identitas diri mereka. Faktor dari luar diri mereka, yaitu lingkungan pergaulan mereka yang kebanyakan adalah anak-anak punk.
\end{abstract}

Kata-kata Kunci: punk, gaya hidup

tanpa aturan, berantakan, dan berandalan. Pandangan ini disebabkan sebagian masyarakat melihat komunitas punk dari gaya dandanan 
mereka. Bagi sebagian orang kemunculan komunitas punk itu cukup mengganggu kenyamanan, macam-macam pemaknaan negatif sering dicapkan kepada para punker. Di sisi lain, persepsi tentang menjadi punk itu sendiri juga disalahpahami oleh sebagian generasi muda yang mengidentikkan dirinya sebagai punker. Sebagian remaja mengartikan punk sebagai hidup bebas tanpa aturan, pemahaman yang salah dan setengah-setengah itu mengakibatkan banyak dari mereka melakukan tindakan yang meresahkan masyarakat, salah satu contoh kecilnya mabukmabukan di muka umum secara bergerombol atau meminta uang secara paksa kepada masyarakat. Biasanya ciri khas mereka terlihat dari busana yang di gunakan, seperti sepatu boots, potongan rambut mohawk ala suku Indian dan diwarnai dengan warna-warna yang terang, memakai rantai, jaket kulit, celana jeans ketat dan kaos yang lusuh.

Masyarakat awam menilai punk adalah segerombolan remaja yang berperilaku negatif, dengan adanya perilaku-perilaku yang kurang terpuji yang dilakukan oleh para punker itu sendiri serta di dukung hingar bingar musik punk dan lirik yang berisi kecaman perlawanan semakin menyempurnakan miringnya pandangan masyarakat tentang punk, padahal itu bukan cerminan punk yang sebenarnya.

Bandung adalah salah satu kota besar di Indonesia, sama halnya dengan kota besar yang lain seperti Jakarta, punker juga bisa ditemukan di kota Bandung, yang bisa kita jumpai di beberapa tempat keramaian dan di jalanan, selain itu terdapat pula komunitaskomunitas punk yang bertempat di berbagai daerah di wilayah Bandung, seperti di Cicalengka, disana terdapat komunitas punk yang tergolong unik dan kreatif, mereka menyebutnya sebagai komunitas Punklung (baca : pang-lung).

Komunitas Punklung , berbeda dengan komunitas punk yang lain yang ada di Indonesia bahkan dunia, yang mana komunitas ini terbentuk dengan tujuan ingin melestarikan budaya lokal dengan memainkan alat musik daerahnya yaitu calung meskipun dengan setelan dan gaya punk. hal itu menjadikan minat peneliti untuk mengetahui bagaimana gaya hidup komunitas Punklung dalam kesehariannya, dengan membawa nilai budaya apakah gaya hidup mereka sama ataukah berbeda dengan komunitas-komunitas punk yang ada di Indonesia.

\section{Pengertian Gaya Hidup}

Dalam Alwisol (2006:90) Adler menjelaskan "gaya hidup adalah cara yang unik dari setiap orang dalam berjuang mencapai tujuan khusus yang telah ditentukan orang itu dalam kehidupan tertentu dimana dia berada". Semua orang berpotensi untuk mengembangkan dirinya sesuai dengan gaya hidupnya, artinya setiap orang memiliki tujuan, perasaan inferior, berjuang menjadi superior dan dapat mewarnai atau tidak mewarnai usaha superiornya dengan minat sosial, setiap orang melakukannya dengan gaya hidup yang berbeda-beda.

Chaney (1996:92) mendefinisikan gaya hidup sebagai "cara-cara terpola dalam menginvestasikan aspek-aspek tertentu kehidupan sehari-hari dengan nilai sosial atau simbolik." Pola-pola tindakan ini membedakan antara satu orang dengan orang lain, yang mana gaya hidup merupakan identitas diri di dalam suatu masyarakat modern, hal ini meliputi bagaimana individu dikenal dan diakui keberadaannya oleh masyarakat. Wujud pengakuan ini dapat berupa apresiasi terhadap aspek-aspek simbolik yang melekat pada tubuh individu, oleh karena itu gaya hidup merupakan perwujudan seseorang di dalam lingkungannya menjadi alat untuk menentukan dari golongan manakah ia berasal.

Menurt Adler dalam Alwisol (2006:95), gaya hidup ditentukan oleh "inferioritasinferioritas khusus yang dimiliki seseorang, dapat berupa khayalan atau nyata." Adler dalam Supratiknya mengemukakan bahwa "perasaan inferioritas merupakan perasaan yang muncul akibat kekurangan psikologis atau sosial yang dirasakan secara subjektif maupun perasaan-perasaan yang muncul dari kelemahan atau cacat tubuh yang nyata." Perasaan inferoritas bersumber pada rasa tidak lengkap atau tidak sempurna dalam setiap bidang 
kehidupan sehingga gaya hidup itu merupakan suatu bentuk kompensasi dari inferioritas atau kekurangsempurnaan tertentu.

\section{Aspek-aspek Gaya Hidup}

Menurut Reynold dan Darden dalam Engel, dkk (1990:385) membagi aspek-aspek gaya hidup sebagai berikut, (1) Kegiatan (activities) yaitu tindakan nyata yang dilakukan seseorang. Kegiatan ini meliputi kerja, rutinitas sehari-hari, olahraga, dan lain-lain. (2) Minat (interest) adalah tingkat kegairahan yang menyertai perhatian khusus maupun terus menerus. Minat meliputi keluarga, pekerjaan, komunitas, pola makan, penampilan, lawan jenis dan sebagainya. (3) Pendapat (opinion) merupakan jawaban lisan atau tertulis yang individu berikan sebagai respons terhadap situasi stimulus dimana semacam pertanyaan diajukan. Pendapat digunakan untuk mendeskripsikan penafsiran, harapan dan evaluasi seperti kepercayaan mengenai maksud orang lain, antisipasi sehubungan dengan peristiwa masa yang akan datang dan pertimbangan konsekuensi yang memberi ganjaran atau menghukum dari jalannya tindakan alternatif. (4) Demografi meliputi usia, pendidikan, pekerjaan, pendapatan dan tempat tinggal.

\section{METODE}

Penelitian tentang "Gaya Hidup Punklung (Studi Kasus pada Komunitas Punklung di Cicalengka, Bandung)", jenis penelitian yang digunakan adalah penelitian kualitatif dengan pendekatan studi kasus. Hal ini dilakukan dengan alasan bahwa suatu fenomena atau peristiwa tertentu akan lebih memiliki arti dan makna jika diuraikan dengan kata-kata daripada menggunakan angka. Metode pengumpulan data dalam penelitian ini menggunakan metode observasi partisipan dan wawancara tidak terstruktur. Keabsahan data penelitian ini menggunakan teknik perpanjangan keikutsertaan dan ketekunan pengamatan di lapangan, perpanjangan keiuktsertaan ialah untuk memungkinkan peneliti terbuka terhadap pengaruh ganda, yaitu faktor-faktor kontekstual dan pengaruh bersama pada peneliti dan subjek yang akhirnya mempengaruhi fenomena yang diteliti. Sedangkan ketekunan pengamatan bermaksud menemukan ciri-ciri dan unsurunsur dalam situasi yang sangat relevan dengan persoalan atau isu yang sedang dicari dan kemudian memusatkan diri pada hal-hal tersebut secara rinci. Jika perpanjangan keikutsertaan menyediakan lingkup, maka ketekunan pengamatan menyediakan kedalaman

\section{HASIL DAN PEMBAHASAN}

Gaya hidup punklung dituangkan dalam kehidupan sehari-hari, sekelompok anak muda yang berasal dari kondisi yang sama, yaitu dari ekonomi yang sederhana, dengan psikologis sama, dengan latar belakang yang sama mereka membentuk sebuah komunitas, yang berawal dari minat mereka yang sama yaitu mempunyai jiwa serta memahami nilainilai punk yang mereka dapatkan dari pergaulan, yang kemudian membentuk Punklung, punker yang main calung untuk mengajak masyarakat mencintai budaya lokal dengan tujuan untuk melestarikan budaya yang semakin terkikis dan mulai dilupakan oleh masyarakat Jawa barat, mereka dengan dasar DIY (do it yourself) juga menumbuhkan kepeduliannya terhadap masyarakat kelas bawah dengan menyaurakannya lewat musik.

Menurut Adler dalam Alwisol (2006:95), gaya hidup ditentukan oleh "inferioritas-inferioritas khusus yang dimiliki seseorang, dapat berupa khayalan atau nyata." Adler dalam Supratiknya mengemukakan bahwa "perasaan inferioritas merupakan perasaan yang muncul akibat kekurangan psikologis atau sosial yang dirasakan secara subjektif maupun perasaan-perasaan yang muncul dari kelemahan atau cacat tubuh yang nyata." Perasaan inferoritas bersumber pada rasa tidak lengkap atau tidak sempurna dalam setiap bidang kehidupan sehingga gaya hidup itu merupakan suatu bentuk kompensasi dari inferioritas atau kekurangsempurnaan tertentu. Gaya hidup dapat digunakan sebagai landasan 
untuk memahami tingkah laku seseorang dan melatarbelakangi sifat khas seseorang. Komunitas Punklung berangkat dari kepedulian terhadap masyarakat kelas bawah dan kepedulian terhadap budaya, hal itu tidak lepas dari perasaan-perasaan yang mereka rasakan ketika mereka berasal dari keluarga yang sederhana, jadi lebih meresapi dan tahu akan keadaan rakyat kelas bawah. Sehingga mereka lebih mendalami dan tumbuh semangat yang tinggi untuk lebih peduli terhadap rakyat jelata dan terhadap budaya lokal yang ada. Komunitas Punklung mempunyai rasa kekeluargaan yang tinggi, hal itu tidak lepas dari sifat kebersamaan mereka yang biasa di tampilkan dalam kesehariannya, di sisi lain mereka berasal dari kondisi yang sama yaitu dari ekonomi yang sederhana, dengan psikologis yang sama, sehingga dengan latar belakang yang sama membuat komunitas Punklung menjadi lebih solid, seringnya mereka berkumpul dan berkomunikasi antar sesama anggota, menjadikan mereka tahu akan karakter masing-masing, dan tetap terjaga keharmonisannya hingga sekarang, yang ada di benak mereka adalah tetap bisa berkumpul dan menjaga silaturahmi antar sesama anggota, sangat sederhana memang ketika dengan kondisi jaman yang semakin berkembang, dengan kebutuhan yang semakin meningkat, tapi mereka rela meluangkan waktunya untuk sekedar minum kopi bersama, hal itu dilakukan agar ada sinkronasi antar anggota komunitas, dan tak jarang juga mereka berkumpul untuk membahas tentang kemajuan Punklung dimasa depan. Komunitas Punklung lebih senang dengan kebersamaan dalam kesederhanaan, Punklung tidak mau di eksklusifkan tapi lebih senang sederhana sewajarnya saja, pernah suatu waktu main di Metro tv di tempatkan di tempat mewah, tapi mereka tidak merasa nyaman, mereka juga tidak berorientasi terhadap duit dalam komunitas dan gerakan yang dibawa, tapi lebih mementingkan pelestarian budaya agar dapat berkembang dan dikenal oleh masyarakat. dengan adanya budaya lokal yang mulai terkikis, tanggung jawab moral sebagai komunitas punk yang peduli budaya menjadikan semangat tanpa harus diganti dengan duit.
Gaya hidup adalah cara yang unik dari setiap orang dalam berjuang mencapai tujuan khusus yang telah ditentukan orang itu dalam kehidupan tertentu dimana dia berada" (Adler dalam Alwisol 2006:90). Semua orang berpotensi untuk mengembangkan dirinya sesuai dengan gaya hidupnya. Artinya, setiap orang memiliki tujuan, perasaan inferior, berjuang menjadi superior dan dapat mewarnai atau tidak mewarnai usaha superiornya dengan minat sosial, setiap orang melakukannya dengan gaya hidup yang berbeda-beda yang ditentukannya sesuai dengan tempat dimana dia berada. Pada awalnya komunitas punklung berasal dari segerombolan anak muda yang mempunyai kesamaan dalam pemikiran dan gaya punk.

\section{KESIMPULAN}

Gaya hidup punklung di Cicalengka Bandung dipengaruhi oleh empat unsur utama, keempat unsur utama tersebut adalah musik, gaya berbusana, tempat berkumpul atau istilah kerennya tongkrongan, dan pemikiran atau cara pandang terhadap berbagai permasalahan hidup, keempat unsur utama tersebut dipercaya dapat semakin mengeratkan hubungan emosional antara komunitas punk.

Faktor pendorong adanya komunitas punklung karena dorongan dari dalam diri mereka yang ingin menjadi anak punk atau suka dengan punk karena minat mereka yang besar terhadap musik dan ideology punk itu sendiri yang peduli terhadap masyarakat kelas bawah dan adanya keinginan mereka untuk melestarikan budaya lokal yang mulai terkikis dan dikhawatirkan akan dilupakan yaitu calung meskipun dengan setelan punk, mereka berasal dari lingkungan yang sama, yaitu dari keluargakeluarga yang sederhana membuat mereka lebih mengerti tentang masyarakat kelas bawah, hal itu di dukung pula dengan adanya penerimaan keluarga akan dirinya sebagai punker, sedangkan faktor dari luar diri mereka, yaitu lingkungan pergaulan mereka yang kebanyakan adalah anak-anak punk.

Komunitas Punklung merupakan komunitas punk yang mengarah pada kegiatan 
yang positif, mereka mempunyai pandangan yang positif terhadap dirinya sendiri dan orang lain, Punklung pernah mengalami masa negatif saat awal terbentuknya Punklung pada tahun 2000-an, yang mana aktivitas mereka sangat akrab sekali dengan minum-minuman keras dan kurang mementingkan nilai ibadah terhadap agamanya. Setelah lebih dari sepuluh tahun berdiri hal itu mulai berubah, mereka meninggalkan hal-hal negatif seperti minumminuman keras dan mulai memandang agama menjadi bagian yang penting dalam kehidupannya, hal itu di pengaruhi oleh usia mereka yang semakin dewasa dan sebagian sudah berumah tangga serta adanya kesadaran diri, adanya rasa malu ketika Punklung yang di kenal sebagai komunitas punk yang bisa dan mau melestarikan budaya dengan calungnya di kotori dengan hal-hal negatif seperti minumminuman keras.

Gaya hidup punklung yang awalnya urakan pada akhirnya justru terkenal di kalangan masyarakat luas, terutama gaya berpakaian, potongan rambut dan pola tingkah laku yang terkesan ekstrem. Mereka dengan sangat berani mencukur habis rambut dan hanya menyisakan pada bagian tengahnya, yang biasa di sebut dengan mohawk, belum lagi tambahan berbagai warna mencolok yang semakin menambah kesan ekstrem pada kepala mereka.

Punk yang memang sudah terkesan ekstrem dengan gaya rambutnya, ternyata masih belum puas hanya hal itu. Mereka kemudian menciptakan gaya berpakaian yang berbeda dari manusia kebanyakan. Mereka biasanya menggunakan kaos hitam, jaket kulit, sepatu booth, rantai, dan banyak asesoris berupa kalung dan gelang yang di pakai. Gaya berpakain tersebut mereka jaga guna memperkuat image anti kemapanan, semua itu akibat dari keadaan yang mereka anggap sangat tidak berpihak pada mereka. Gaya punk yang seperti ini, mau tidak mau berakibat pada pengertian punk di masyarakat yang menjadi buruk. Mereka sering di anggap kaum perusuh, bergerombol tidak jelas, nongkrong-nongkrong, pemabuk berat, dan orang-orang yang bisanya hanya bisa membuat rusuh.

Namun, pedapat seperti itu sepertinya juga tidak adil bila ditujukan pada semua anak punk. banyak di antara mereka yang justru berkarya dan melakukan hal baik dalam hidupya. Mereka menciptakan berbagai lagu yang bernada protes" mereka banyak bercerita tentang ketidakpuasan mereka terhadap keadaan politik, soisal, ekonomi, ideology.

\section{SARAN}

Berdasarkan hasil penelitian dan merujuk pada manfaat penelitian, maka saran yang dapat diberikan antara lain pemerintah sebaiknya bekerjasama dengan komunitaskomunitas punk dengan pendekatan humanistik dalam upaya meningkatkan kualitas sumber daya manusia, dengan pertimbangan besar kecilnya manfaat dan nilai-nilai yang ada di dalam gerakan-gerakan tersebut.

Para punker baik dalam komunitas atau individu diharapkan berperan aktif dan positif dalam menyampaikan gerakan-gerakan yang mereka bawa. Sehingga menjadi sosok yang mampu mewujudkan dirinya sebagai bagian dari masyarakat luas dan keluarga yang peduli terhadap lingkungan sosial, hal itu akan mengurangi stigma-stigma negatif pada masyarakat yang merugikan para punker itu sendiri.

Peneliti selanjutnya diharapkan dapat memaksimalkan teknik pengumpulan data, seperti wawancara, observasi, dokumentasi agar lebih dapat bervariasi sehingga diperoleh data yang akurat dan tepat bagi keberhasilan penelitian lebih lanjut mengenai hal-hal yang berkaitan dengan gaya hidup punk dan hasil penelitian ini diharapkan dapat memberikan sumbangan bagi perkembangan ilmu psikologi terutama psikologi sosial tentang gaya hidup.

\section{DAFTAR RUJUKAN}

\author{
Alwisol. 2006. Psikologi Kepribadian (Edisi \\ Revisi). Malang: UMM Press
}


Chaney, David. 1996. Lifestyles: Sebuah Pengantar Komprehensif. Yogyakarta: Jalasutra

Chaplin, J.P. 2009. Kamus Lengkap Psikologi. Jakarta: PT RajaGrafindo Persada

Choiriyah, Miyah. 2009. Gaya Hidup Komunitas Punk di Kota Malang (online). Malang : UMM

Christopher, R.P. 2011. Being in the Know: Punk, Confrontation, and the Process of Validating Truth Claims. Chicago: Loyola University Chicago

Engel, F.J, Blackwell, D.R dan Miniard, W.P. 1990. Perilaku Konsumen, Jilid 1. Jakarta: Binarupa Aksara

Feist, Jess \& Gregory, Jess, F. 2008. Theories of Personality. Yogyakarta: Pustaka Pelajar

Hebdige, D. 1999. Asal-Usul \& Ideologi Subkultur Punk. Yogyakarta: Penerbit Buku Baik

Hurlock, E. B. 1980. Psikologi Perkembangan: Suatu Pendekatan Sepanjang Rentang Kehidupan (Edisi kelima). Jakarta: Erlangga

Moleong, Lexy. 2010. Metode Penelitian Kualitatif (Edisi Revisi). Bandung: PT. Remaja Rosdakarya

O'connor, A. 2004. Punk and Globalization : Spain and Mexico. International Juornal of Cultural Studies. 1 Juni 2004.

Sari, N. K. 2011. Gaya Hidup Komunitas Punk di Kota Surakarta (online). Surakarta : UNS

Sugiyono. 2008. Metode penelitian Kuantitatif, Kualitatif dan $R \& D$. Bandung: Alfabeta

Widya, G. 2010. Punk (Ideologi Yang Disalahpahami). Jogjakarta: Garasi House of

Book.

Yulianti, Fitia. 2012. Gaya Hidup Komunitas Punk di Yogyakarta (online). Yogyakarta : UNY 